\title{
PROSES BERPIKIR MAHASISWA QUITTER DALAM MENYELESAIKAN MASALAH GEOMETRI DENGAN PEMBERIAN SCAFFOLDING DI JURUSAN PENDIDIKAN MATEMATIKA IAIN BUKITTINGGI
}

\author{
M. Imamuddin \\ Dosen Pendidikan Matematika FTIK IAIN Bukittinggi \\ Jalan Raya Gurun Aur Kubang Putih, Banuhampu Kabupaten Agam \\ Email: m.imamuddin76@yahoo.co.id
}

\begin{abstract}
The role of lecturers to improve students mathematical errors and to lead students to achieve higher potential developments is by (1) facilitating students to connect their current knowledge to the previous ones, (2) encouraging students to continue learning, (3) providing sufficient assistance (scaffolding) to the students toward independence, (4) trigger students to always think so that the development of the scheme is always increasing, and (5) help students internalize the knowledge so that ultimately can construct his knowledge. Scaffolding is one way to assist students in overcoming difficulties solving geometry problems. The purpose of this research is to describe quitter students' thinking process in solving geometry problem by giving scaffolding in Mathematics Education Department of IAIN Bukittinggi. This research employs qualitative research that seeks to express in depth the process of thinking of quitter students in solving geometry problem by giving scaffolding, by using study process of student mathematics concept and its diagnosis through cognitive map. The results showed that quitter students' thinking process in solving geometry problem with scaffolding was unique and interesting. Each student has different ways of solving problems. Problem of difficulty are also experienced by quitter students. Scaffolding provided varies according to the needs of each student to develop his thinking process. By providing scaffolding in general, the process of thinking the subject of research to develop in line with the structure of the problem.
\end{abstract}

Key words: Process of Thinking, Student Quiter, Problem Solving and Geometry

\section{PENDAHULUAN}

Semakin banyak mahasiswa maka semakin tinggi kemajemukan yang terjadi, seperti kemajemukan kecerdasan, emosional, spritual, budaya, ras dan lain-lainnya. Peneliti sebagai dosen geometri di semester dua dan tiga sangat merasakan sekali kemajemukan yang terjadi terutama kemajemukan kecerdasan mengatasi masalah/adversity quotient dalam menyelesaikan soal-soal geometri pada mahasiswa pendidikan matematika.
Adversity Quotient (AQ) adalah kecerdasan mengatasi masalah (daya juang), yaitu kecerdasan seseorang dalam menghadapi kesulitan yang menghadangnya. Beberapa istilah yang sering dipadankan dengan $A Q$, misalnya kecerdasan keuletan dan tahan banting (Sumardi, 2006), kecerdasan ketangguhan (Efendi, 2005) dan (Sumardi, 2006), potensi kegigihan (Subiyanto, 2006), kehandalan mental (Laksomono, 2006), kecerdasan ketahanmalangan (Candiasa, 2006). 
Stoltz (2000) mengelompokkan orang ke dalam tiga kategori $A Q$, yaitu: quitter $(A Q$ rendah), camper ( $A Q$ sedang), dan climber $(A Q$ tinggi). Berdasarkan pendapat tersebut, mahasiswa dapat dikelompokkan dalam tiga kategori yaitu mahasiswa memiliki AQ rendah, AQ sedang, dan AQ tinggi berturut-turut disebut mahasiswa quitter, camper, dan climber.

Mahasiswa quitter berusaha menjauh dari permasalahan, begitu melihat kesulitan ia akan memilih mundur, dan tidak berani menghadapi permasalahan. Mereka yang quitter cenderung akan berhenti di tengah jalan ketika pesaingnya terus berjalan tanpa henti. Stoltz (2000) mengemukakan karakteristik orang quitter sebagai berikut: (a) menolak untuk "mendaki", (b) bekerja sekedar untuk hidup, (c) cenderung menghindari tantangan, (d) jarang sekali memiliki persahabatan yang sejati, (e) cenderung menolak perubahan, (f) terampil menggunakan kata-kata yang sifatnya membatasi, misalnya: tidak mau, mustahil, ini konyol, belum waktunya, bukan macam saya, dsb., (g) kemampuannya kurang, (h) tidak memiliki visi dan keyakinan akan masa depan, dan (i) konstribusinya dalam tim sangat kecil.

Pesertadidik, mulai dari pendidikan dasar, pendidikan menengah sampai perguruan tinggi belajar matematika. Salah satu karakteristik matematika adalah objek kajiannya abstrak. Sehingga belajar matematika merupakan kegiatan mental yang tinggi yang membutuhkan konsentrasi tinggi. Menurut Hermes (dalam Marpaung, 1999) semua konsep matematika memiliki sifat abstrak sebab hanya ada dalam pikiran manusia. Hanya pikiran yang dapat "melihat" objek matematika.

Sifat abstrak matematika, menjadikan pemecahan masalah secara eksplisit menjadi tujuan pembelajaran matematika dan tertuang dalam kurikulum. Untuk memecahkan masalah, Polya (1973) menawarkan suatu strategi yang terdiri atas empat langkah: memahami masalah (understanding the probem), menyusun rencana penyelesaian masalah (devising a plan), melaksanakan rencana penyelesaian masalah (carrying out the plan), dan mengecek penyelesaian masalah (looking back).

Dalam belajar matematika dan menyelesaikan soal matematika, mahasiswa melakukan proses berpikir. Dalam benak mahasiswa terjadi proses berpikir sehingga mahasiswa dapat sampai pada jawaban dari permasalahan. Kesalahan proses berpikir dimungkinkan terjadi karena kurangnya latihan pemecahan masalah dan dimungkinkan terjadi karena kesalahan konsep, prinsip dan skill yang dilatihkan oleh dosen dalam proses pembelajaran. Kesalahan proses berpikir ini menyebabkan banyak mahasiswa memperoleh nilai yang rendah, berdasarkan data nilai geometri rata-rata mahasiswa memperoleh nilai $\mathrm{C}$, dengan rincian $20 \%$ mahasiswa memperoleh nilai $\mathrm{E}, 57 \%$ mahasiswa memperoleh nilai $\mathrm{C}$, $20 \%$ mahasiswa memperoleh $\mathrm{B}$ dan hanya $3 \%$ mahasiswa yang mampu memperoleh nilai A.

Dalam pembelajaran matematika proses berpikir ini kurang mendapat perhatian dari para dosen. Hal ini sejalan dengan pengalaman penulis dalam mengajar geometri bidang dan ruang dan ditambah dengan hasil diskusi dengan beberapa dosen sejawat yang samasama mengajar di pendidikan matematika, dimana jika memberikan tugas ataupun tes kepada mahasiswa, pada umumnya dosen hanya memperhatikan langkah-langkah pengerjaan dan hasil akhir penyelesaian mahasiswa tanpa memperhatikan bagaimana sebenarnya mahasiswa itu dapat sampai pada jawaban itu.

Jika jawaban mahasiswa berbeda dengan langkah-langkah yang seharusnya atau proses penyelesaian yang ada, dosen langsung menyalahkan jawaban tersebut dan memberikan nilai sesuai dengan hasil pekerjaan mahasiswa tanpa terlebih dahulu menelusuri alasan mahasiswa mengapa jawabannya demikian. Padahal menurut Yulaelawati (2004) salah satu peran guru/dosen dalam pembelajaran matematika adalah membantu pesertadidik/mahasiswa mengungkapkan bagaimana proses yang berjalan dalam pikirannya ketika memecahkan masalah, misalnya dengan cara meminta 
pesertadidik/mahasiswa menceritakan langkah penyelesaian yang ada dalam pikirannya. Hal ini diperlukan untuk mengetahui kesalahan yang terjadi dan menata jaringan pengetahuan pesertadidik/mahasiswa.

Proses berpikir terjadi dalam otak manusia. Informasi-informasi yang masuk diolah di dalamnya, sehingga apa yang sudah ada di dalam perlu penyesuaian bahkan perubahan sama sekali. Proses demikian dinamakan adaptasi. Adaptasi skema dapat dilakukan dengan dua cara yaitu asimilasi dan akomodasi bergantung pada jenis informasi/pengalaman yang masuk ke dalam struktur mental. Asimilasi terjadi ketika struktur masalah yang dihadapi sesuai dengan skema yang sudah dimiliki, sehingga struktur masalah dapat diintegrasikan langsung ke dalam skema yang ada.

Sedangkan akomodasi terjadi ketika struktur skema yang dimiliki belum sesuai dengan struktur masalah yang dihadapi, sehingga perlu mengubah skema lama agar sesuai dengan struktur masalah. Apabila yang terjadi adalah pembentukan skema yang betulbetul baru, maka yang terjadi adalah proses berpikir abstraksi. Ada tiga macam proses berpikir abstraksi, yaitu abstraksi empirik, abstraksi empirik semu, dan abstraksi reflektif.

Mengetahui proses berpikir mahasiswa dalam menyelesaikan suatu masalah matematika sangat penting bagi dosen. Dosen harus memahami cara berpikir mahasiswa dan cara mahasiswa mengolah informasi yang masuk sambil mengarahkan mahasiswa untuk mengubah cara berpikirnya jika itu ternyata diperlukan. Dengan mengetahui proses berpikir mahasiswa, dosen dapat melacak letak dan jenis kesalahan yang dilakukan mahasiswa. Kesalahan yang diperbuat mahasiswa dapat dijadikan sumber informasi belajar dan pemahaman bagi mahasiswa. Yang tak kalah pentingnya adalah dosen dapat merancang pembelajaran yang sesuai dengan proses berpikir mahasiswa.

Oleh karena itu, pengungkapan proses berpikir mahasiswa dalam memecahkan masalah perlu dilakukan sehingga dosen dapat segera menata/merapikan skema/struktur kognitif mahasiswa. Proses menata/merapikan skema/struktur kognitif mahasiswa dapat dilakukan dengan teknik scaffolding. Larkin (Cahyo, 2010) menyatakan bahwa scaffolding adalah salah satu prinsip pembelajaran yang efektif yang memungkinkan para pembelajar untuk mengakomodasikan kebutuhan mahasiswa. Scaffolding sebagai bantuan yang besar kepada mahasiswa selama tahap awal dan kemudian mengurangi bantuan tersebut dan memberikan kesempatan kepada mahasiswa untuk mengerjakan pekerjaannya sendiri dan mengambil alih tanggung jawab pekerjaan itu. Bantuan yang diberikan dapat berupa petunjuk, peringatan, dorongan menguraikan masalah kedalam bentuk lain yang memungkinkan mahasiswa dapat mandiri.

Beberapa penelitian terdahulu yang meneliti tentang proses berpikir antara lain : Sudarman (2011), Sri Adi Widodo (2012), Muhtarom dan Sugiyanti (2015), Muhammad Yani, M. Ikhsan, dan Marwan (2016). Secara umum penelitian terdahulu membahas tentang proses berpikir dalam memecahkan masalah matematika. Sudarman meneliti proses berpikir siswa Quitter di Sekolah Menengah Pertama dalam menyelesaikan masalah matematika, Muhtarom dan Sugiyanti meneliti proses berpikir mahasiswa dengan pemberian scaffolding, dan Muhammad Yani, M. Ikhsan, dan Marwan meneliti proses berpikir siswa sekolah menengah pertama ditinjau dari Adversity Quotient, sedangkan Sri Adi Widodo meneliti proses berpikir mahasiswa berdasarkan dimensi teacher dan dimensi healer. Berdasarkan hasil penelitian Muhtarom dan Sugiyanti yang menyimpulkan Mahasiswa yang berkemampuan matematika sedang dan rendah membutuhkan scaffolding untuk dapat memecahkan masalah.

Berdasarkan permasalahan di atas khususnya dari hasil penelitian Sudarman, Muhtarom dan Sugiyanti, maka penulis tertarik untuk mendeskripsikan proses berpikir mahasiswa Quitter dalam menyelesaikan masalah geometri dengan pemberian 
scaffolding di Jurusan Pendidikan Matematika IAIN Bukittinggi”.

\section{Kajian Pustaka}

Dalam kamus besar Bahasa Indonesia (2007), berpikir berasal dari kata dasar "pikir" yang berarti akal budi, ingatan, angan-angan, pendapat atau pertimbangan. Berpikir berarti menggunakan akal budi untuk mempertimbangkan dan memutuskan sesuatu. Sfard (2009) menyatakan : “...thinking is a primary process that unfolds naturally "from inside" the person...". Berpikir adalah proses utama yang terjadi dalam diri seseorang secara alami. Senada dengan itu, Radford (2009) mengatakan: "...thinking is a pure mental activity-something immaterial, independent of the body, occurring in the head". Berpikir adalah suatu aktivitas mental yang alami sesuatu yang tidak berwujud, kebebasan dari tubuh, terjadi di dalam kepala. Oleh karena itu, berpikir tidak dapat dilihat oleh indera manusia.

Plato (dalam Sumadi Suryabrata, 2004:

54) menyatakan, berpikir adalah berbicara dalam hati. Bigot dkk (dalam Sumadi Suryabrata, 2004: 54) mengatakan, berpikir adalah meletakkan hubungan antara bagianbagian pengetahuan kita. Bagian-bagian pengetahuan kita yaitu segala sesuatu yang telah kita miliki, yang berupa pengertianpengertian dan dalam batas tertentu juga tanggapan-tanggapan. Santrock (2009) menjelaskan, berpikir melibatkan kegiatan manipulasi dan mentransformasi informasi dalam memori untuk membentuk konsep, menalar, berpikir secara kritis, membuat keputusan, berpikir secara kreatif, dan memecahkan masalah. Menurut Yansen $M$. (dalam Aris Yuwono, 2010), berpikir atau proses kognitif adalah proses yang terdiri atas penerimaan informasi (dari luar atau dari dalam diri siswa), pengolahan, penyimpanan dan pengambilan kembali informasi itu dari ingatan siswa. Pengetahuan terbentuk melalui proses pengorganisasian pengetahuan baru dengan struktur yang sudah ada setelah pengetahuan baru itu diinterprestasikan oleh struktur yang telah ada.
Ruggiero (1998) mengarartikan berpikir sebagai suatu aktivitas mental untuk membantu memformulasikan atau memecahkan suatu masalah, membuat suatu keputusan, atau memenuhi hasrat keingintahuan. Pendapat ini menunjukkan bahwa ketika seseorang merumuskan suatu masalah, memecahkan masalah, ataupun ingin memahami sesuatu, maka ia melakukan suatu aktivitas berpikir.

Individu merupakan partisipan aktif dalam proses memperoleh dan menggunakan pengetahuan. Individu berpikir secara aktif dalam membentuk wawasannya tentang kenyataan, memilih aspek-aspek penting dari pengalaman untuk disimpan dalam ingatan atau digunakan dalam pemecahan masalah. Menurut Imamuddin (2012) menerangkan, berpikir sebagai suatu kemampuan mental seseorang dapat dibedakan menjadi beberapa jenis, antara lain berpikir logis, analitis, sistematis, kritis dan kreatif. Berpikir logis dapat diartikan sebagai kemampuan berpikir siswa untuk menarik kesimpulan yang sah menurut aturan logika dan dapat membuktikan bahwa simpulan itu benar (valid) sesuai dengan pengetahuan-pengetahuan sebelumnya yang sudah diketahui. Berpikir analitis adalah kemampuan berpikir siswa dalam menguraikan, memperinci dan menganalisis informasi yang digunakan untuk memahami suatu pengetahuan dengan menggunakan akal pikiran yang logis, bukan berdasar atas tebakan atau perasaan.

Berpikir sistematis adalah kemampuan berpikir untuk mengerjakan atau menyelesaikan suatu tugas dengan urutan, tahapan, langkahlangkah atau perencanaan yang tepat, efektif, dan efisien. Berpikir kritis dapat dipandang sebagai kemampuan siswa untuk membandingkan dua atau lebih informasi yang dimiliki. Bila terdapat perbedaan atau persamaan, maka ia akan mengajukan pertanyaan dengan tujuan untuk mendapatkan kejelasan. Berpikir kreatif adalah suatu rangkaian tindakan yang dilakukan orang dengan menggunakan akal budinya untuk menciptakan buah pikiran baru dari kumpulan ingatan yang berisi berbagai ide, keterangan, konsep, pengalaman dan pengetahuan. 
Thomas, et. al. (2001) menyatakan, berpikir tingkat tinggi menempatkan aktifitas berpikir pada jenjang yang lebih tinggi dari sekedar menyatakan fakta. Hal yang menjadi perhatian berpikir tingkat tinggi adalah apa yang dilakukan terhadap fakta. Siswa harus memahami fakta, menghubungkan fakta satu dengan fakta yang lainnya, mengkategorikan, memanipulasi, menggunakannya bersama situasi yang baru dan menerapkannya dalam mencari pemecahan baru terhadap permasalahan baru.

Dalam penelitian ini yang dimaksud berpikir adalah suatu aktifitas mental yang dilakukan oleh siswa (terdiri atas penerimaan informasi baik dari luar atau dari dalam diri siswa), pengolahan, penyimpanan, dan pengambilan kembali informasi itu dari ingatan siswa untuk memecahkan suatu masalah.

Proses berpikir terjadi di dalam otak manusia sehingga proses berpikir sulit untuk diamati secara langsung dengan panca indera. Yansen (1986), berpendapat bahwa proses berpikir atau proses kognitif adalah proses yang terdiri atas penerimaan informasi (dari luar atau dari dalam diri siswa), pengolahan, penyimpanan, dan pengambilan kembali informasi itu dari ingatan siswa. Herman dan Siswono (dalam Siti Nunsiyah, 2011:12), menyatakan dalam proses belajar matematika terjadi proses berpikir, sebab seseorang dikatakan berpikir bila orang itu melakukan kegiatan mental dan orang yang belajar matematika pasti melakukan kegiatan mental. Dalam berpikir, seseorang akan menyusun hubungan antara bagian-bagian informasi yang direkam sebagai pengertian-pengertian. Proses berpikir biasa dilakukan seseorang bila dihadapkan pada suatu masalah. Para ahli mendefinisikan proses berpikir sebagai proses mental yang bertujuan memecahkan masalah. Menurut Solso (2007: 402), ada 3 tahap proses berpikir dalam memecahkan suatu masalah.

Beberapa ahli mengemukakan cara untuk dapat melihat proses berpikir seseorang. Charters (2003) mengatakan: "Used a keep talking sign to remind participant to verbalize all thoughts without addressing them in speech which might interfere with those thoughts". Makna kalimat tersebut adalah bahwa proses berpikir dapat diketahui dengan cara selalu bertanya pada peserta untuk verbalisasi semua pikiran tanpa menyapa mereka yang mungkin mengganggu pikiran. Selain itu Charters juga mengatakan bahwa: "collected data by audiotaping participants think-aloud utterances while sitting next to, not across from, them to minimize intimidation and taking informal written notes on their behaviour and tone of voice".

Makna kalimat di atas adalah mengumpulkan data dengan rekaman audio ucapan peserta think-aloud sambil duduk di samping, bukan di seberang mereka untuk meminimalkan intimidasi dan membuat catatan tertulis informal pada perilaku mereka dan nada suara.

Proses berpikir dalam penelitian ini adalah proses berpikir mahasiswa dalam mengerjakan atau menyelesaikan soal/masalah geometri. Setelah mahasiswa menyelesaikan masalah geometri, mahasiswa diwawancarai berdasarkan hasil kerjanya.

Untuk membantu mahasiswa dalam memahami konsep-konsep matematika yang sedang diopelajari, dosen harus mampu mendorong atau memberi bantuan (scaffolding). Larkin (Cahyo, 2010) menyatakan bahwa scaffolding adalah salah satu prinsip pembelajaran yang efektif yang memungkinkan para pembelajar untuk mengakomodasikan kebutuhan mahasiswa. Scaffolding sebagai bantuan yang besar kepada mahasiswa selama tahap awal dan kemudian mengurangi bantuan tersebut dan memberikan kesempatan kepada mahasiswa untuk mengerjakan pekerjaannya sendiri dan mengambil alih tanggung jawab pekerjaan itu. Bantuan yang diberikan dapat berupa petunjuk, peringatan, dorongan menguraikan masalah kedalam bentuk lain yang memungkinkan mahasiswa dapat mandiri.

Scaffolding diberikan dengan melihat, mendengar, dan memahami proses berpikir siswa serta ...Gestures in question and revoicing to ELLs in repair of mathematical errors yaitu gerakan dan kalimat pertanyaan 
yang mudah dipahami siswa sehingga dapat memperbaiki kesalahan matematika.

Peran dosen untuk memperbaiki kesalahan matematika mahasiswa dan untuk mengantarkan mahasiswa mencapai perkembangan potensial yang lebih tinggi adalah dengan cara (1) memfasilitasi mahasiswa agar mahasiswa mampu mengaitkan pengetahuan baru dengan pengetahuan lama, (2) membangkitkan mahasiswa untuk terus belajar, (3) memberi bantuan secukupnya (scaffolding) kepada mahasiswa menuju kemandiriannya, (4) memicu mahasiswa untuk senantiasa berpikir sehingga perkembangan skemanya senantiasa bertambah, dan (5) membantu mahasiswa menginternalisasi pengetahuan sehingga pada akhirnya dapat mengkonstruksi pengetahuannya. Scaffolding adalah salah satu cara untuk membantu mahasiswa dalam mengatasi kesulitan menyelesaikan masalah geometri.

Menurut Saad \& Ghani (2008: 120), pemecahan masalah adalah suatu proses terencana yang perlu dilaksanakan agar memperoleh penyelesaian tertentu dari sebuah masalah yang mungkin tidak didapat dengan segera. Polya (1973: 3) mendefinisikan bahwa pemecahan masalah sebagai usaha mencari jalan keluar dari suatu kesulitan. Menurut Goldstein dan Levin sebagaimana dikutip oleh Rosdiana \& Misu (2013: 2), pemecahan masalah telah didefinisikan sebagai proses kognitif tingkat tinggi yang memerlukan modulasi dan kontrol lebih dari keterampilan rutin atau dasar.

Branca, sebagaimana dikutip oleh Syaiful (2012: 37), mengungkapkan bahwa (1) kemampuan pemecahan masalah merupakan tujuan umum pengajaran matematika, bahkan sebagai jantungnya matematika; (2) pemecahan masalah meliputi metode, prosedur, dan strategi merupakan proses inti dan utama dalam kurikulum matematika; dan (3) pemecahan masalah merupakan kemampuan dasar dalam belajar matematika.
Pada saat memecahkan masalah matematika, siswa dihadapkan dengan beberapa tantangan seperti kesulitan dalam memahami soal. Hal ini disebabkan karena masalah yang dihadapi bukanlah masalah yang pernah dihadapi siswa sebelumnya. Ada beberapa tahap pemecahan masalah yang dikenalkan oleh para matematikawan dan para pengajar matematika seperti tahap pemecahan masalah menurut Polya, Krulik dan Rudnick, serta Dewey. Schoenfeld, sebagaimana dikutip oleh Ellison (2009: 17) menyatakan bahwa bukanlah sebuah pengajaran mengenai strategi yang dapat menyebabkan perbedaan dalam memecahkan masalah, lebih dari itu, mempraktikan penyelesaian masalahlah yang kemudian menjadikan sebuah perbedaan. Menurut Saad \& Ghani (2008: 120), siswa perlu melakukan beberapa hal seperti menerima tantangan dari masalah, merencanakan strategi penyelesaian masalah, menerapkan strategi, dan menguji kembali solusi yang diperoleh.

Menurut Matlin, sebagaimana dikutip oleh Herlambang (2013: 17), pemecahan masalah dibutuhkan bilamana kita ingin mencapai tujuan tertentu tetapi cara penyelesaiannya tidak jelas. Dengan kata lain bila seorang siswa dilatih untuk menyelesaikan masalah, maka siswa itu menjadi mempunyai keterampilan tentang bagaimana mengumpulkan informasi yang relevan, menganalisis informasi dan menyadari betapa perlunya meneliti kembali hasil yang diperolehnya.

Berdasarkan beberapa pengertian di atas, dapat disimpulkan bahwa pemecahan masalah dalam matematika adalah suatu aktivitas untuk mencari penyelesaian dari masalah matematika yang dihadapi dengan menggunakan semua bekal pengetahuan matematika yang dimiliki.

Menurut Polya (1973: 5), ada empat tahap pemecahan masalah yaitu; (1) memahami masalah, (2) merencanakan pemecahan, (3) melaksanakan rencana, (4) memeriksa kembali. Pemecahan masalah Polya dapat dilihat pada Gambar 1 berikut. 


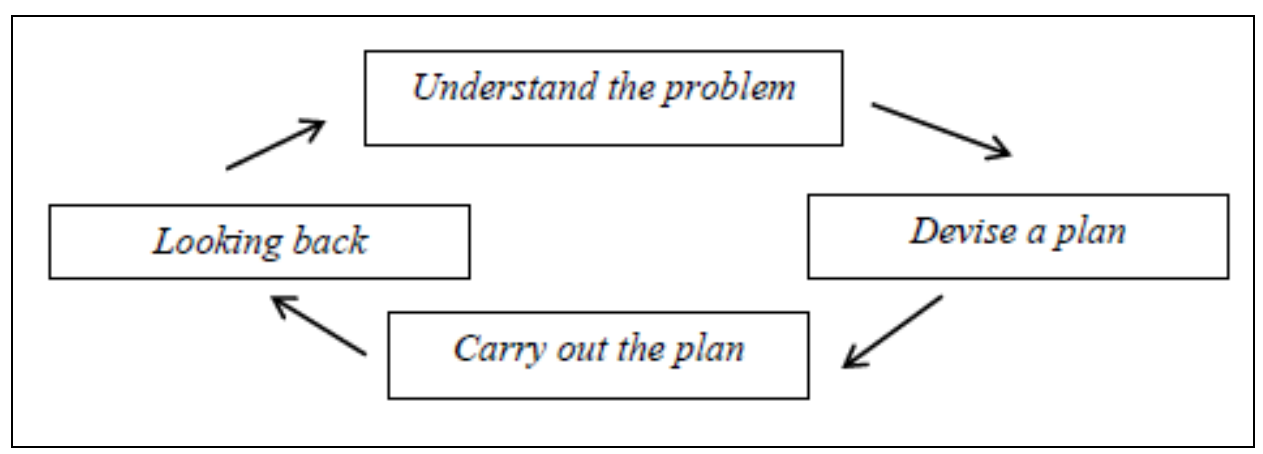

Gambar 1.Tahap Kemampuan Pemecahan Masalah Polya (Polya, 1973: 5)

Menurut Polya (1973: 5-17), empat tahap pemecahan masalah Polya dirinci sebagai berikut:

1. Memahami masalah (understand the problem)

Tahap pertama pada penyelesaian masalah adalah memahami soal. Siswa perlu mengidentifikasi apa yang diketahui, apa saja yang ada, jumlah, hubungan dan nilai-nilai yang terkait serta apa yang sedang mereka cari. Beberapa saran yang dapat membantu siswa dalam memahami masalah yang kompleks: (1) memberikan pertanyaan mengenai apa yang diketahui dan dicari, (2) menjelaskan masalah sesuai dengan kalimat sendiri, (3) menghubungkannya dengan masalah lain yang serupa, (4) fokus pada bagian yang penting dari masalah tersebut, (5) mengembangkan model, dan (6) menggambar diagram.

2. Membuat rencana (devise a plan)

Siswa perlu mengidentifikasi operasi yang terlibat serta strategi yang diperlukan untuk menyelesaikan masalah yang diberikan. Hal ini bisa dilakukan siswa dengan cara seperti: (1) menebak, (2) mengembangkan sebuah model, (3) mensketsa diagram, (4) menyederhanakan masalah, (5) mengidentifikasi pola, (6) membuat tabel, (7) eksperimen dan simulasi, (8) bekerja terbalik, (9) menguji semua kemungkinan, (10) mengidentifikasi sub-tujuan, (11) membuat analogi, dan (12) mengurutkan data/informasi. 3. Melaksanakan rencana (carry out the plan)
Apa yang diterapkan jelaslah tergantung pada apa yang telah direncanakan sebelumnya dan juga termasuk hal-hal berikut: (1) mengartikan informasi yang diberikan ke dalam bentuk matematika; dan (2) melaksanakan strategi selama proses dan penghitungan yang berlangsung. Secara umum pada tahap ini siswa perlu mempertahankan rencana yang sudah dipilih. Jika semisal rencana tersebut tidak bisa terlaksana, maka siswa dapat memilih cara atau rencana lain.

4. Melihat kembali (looking back)

Aspek-aspek berikut perlu diperhatikan ketika mengecek kembali langkahlangkah yang sebelumnya terlibat dalam menyelesaikan masalah, yaitu: (1) mengecek kembali semua informasi yang penting yang telah teridentifikasi; (2) mengecek semua penghitungan yang sudah terlibat; (3) mempertimbangkan apakah solusinya logis; (4) melihat alternatif penyelesaian yang lain; dan (5) membaca pertanyaan kembali dan bertanya kepada diri sendiri apakah pertanyaannya sudah benar-benar terjawab.

Stoltz menyebutkan kesuksesan sangat dipengaruhi oleh kemampuan seseorang dalam mengendalikan atau menguasai kehidupannya sendiri. Kesuksesan juga sangat dipengaruhi dan dapat diramalkan melalui cara seseorang merespons dan menjelaskan kesulitan. Menurut Stoltz, adversity quotient adalah teori yang sesuai dan sekaligus ukuran yang bermakna dan seperangkat instrumen yang diolah sedemikian 
rupa untuk membantu seseorang agar tetap gigih menghadapi kemelut yang penuh tantangan (Stoltz, 2000).

Dalam bukunya, Stoltz menyatakan terdapat tiga tingkatan daya tahan seseorang dalam menghadapi masalah, antara lain:

a. Quitters

Quitters yaitu orang yang memilih keluar, menghindari kewajiban, mundur, dan berhenti. Individu dengan tipe ini memilih untuk berhenti berusaha, mereka mengabaikan menutupi dan meninggalkan dorongan inti yang manusiawi untuk terus berusaha. Dengan demikian, individu dengan tipe ini biasanya meninggalkan banyak hal yang ditawarkan oleh kehidupan.

b. Campers

Campers atau orang-orang yang berkemah adalah orang-orang yang telah berusaha sedikit kemudian mudah merasa puas atas apa yang dicapainya. Tipe ini biasanya bosan dalam melakukan pendakian kemudian mencari posisi yang nyaman dan bersembunyi pada situasi yang bersahabat. Kebanyakan para campers menganggap hidupnya telah sukses sehingga tidak perlu lagi melakukan perbaikan dan usaha.

c. Climbers

Climbers atau si pendaki adalah individu yang melakukan usaha sepanjang hidupnya. Tanpa menghiraukan latar belakang, keuntungan kerugian, nasib baik maupun buruk, individu dengan tipe ini akan terus berusaha.

Beberapa penelitian relevan yang membahas atau meneliti tentang proses berpikir adalah; Sudarman (2011) dengan judul penelitiannya "proses berpikir siswa Quitter pada Sekolah Menengah Pertama dalam menyelesaikan masalah matematika"dengan hasil penelitiannya menyimpulkan, (1)Siswa quitter menghindar dari tugas atau masalah yang diberikan. Ia kurang bersemangat mengerjakan tugas yang diberikan, (2) Siswa quitter dalam memahami masalah matematika adalah abstraksi reflektif sekaligus asimilasi, (3) Siswa quitter dalam menyusun rencana penyelesaian masalah matematika adalah abstraksi reflektif sekaligus asimilasi, (4) Siswa quitter dalam melaksanakan rencana penyelesaian masalah matematika adalah abstraksi empirik-semu sekaligus asimilasi, (5) Siswa quitter memanipulasi benda konkret dalam, melaksanakan, dan mengecek kembali penyelesaian masalah matematika.

Muhtarom dan Sugiyanti (2015) dengan judul penelitiannya "PROSES BERPIKIR MAHASISWA PENDIDIKAN MATEMATIKA IKIP PGRI SEMARANG DALAM MEMECAHKAN MASALAH TRIGONOMETRI DENGAN PEMBERIAN SCAFFOLDING" dengan hasil penelitiannya, (1) Untuk mahasiswa yang berkemampuan matematika tinggi, pada umumnya mereka tidak membutuhkan scaffolding dalam memecahkan masalah, mereka sudah mampu memahami masalah, menyusun rencana pemecahan masalah, mampu melaksanakan rencana pemecahan masalah dengan benar dan mampu memberikan argumentasi dari setiap langkah yang dilaksanakan, (2) Mahasiswa yang berkemampuan matematika sedang dan rendah membutuhkan scaffolding untuk dapat memecahkan masalah.

\section{METODE PENELITIAN}

Penelitian ini termasuk pada penelitian kualitatif. Penelitian ini berusaha mengungkapkan secara mendalam proses berpikir mahasiswa quitter dalam menyelesaikan masalah geometri dengan pemberian scaffolding. Pemecahkan masalah geometri mengacu pada langkah-langkah pemecahan masalah model Polya. Data yang dikumpulkan dalam penelitian ini bersifat kualitatif eksploratif, yaitu penjelasan aktual tentang bagaimana mahasiswa menyelesaikan masalah matematika dengan mengacu langkahlangkah Polya.

Sebagai subjek penelitian adalah mahasiswa Pendidikan Matematika yang duduk pada semester III Jurusan Pendidikan Matematika IAIN Bukittinggi TA. 2016/2017. Subjek penelitian diambil dengan teknik porposive sampling yaitu 2 mahasiswa yang berkemampuan rendah (Quitter). Pengambilan 
subjek penelitian berdasarkan hasil tes geometri dan didukung dengan pertimbangan hasil penilaian tugas-tugas yang dikerjakan mahasiswa pada pertemuan sebelumnya.

Instrumen yang sangat penting/utama dalam penelitian ini adalah peneliti sendiri. Instrumen lainnya adalah lembar tugas/Soal Pemecahan Masalah (SPM) matakuliah geometri (geometri bidang dan ruang) dan wawancara tidak terstruktur dengan menggunakan Scaffolding. Penyusunan instrumen SPM diawali dengan mengkaji materi matematika yang ditetapkan dalam standar kelulusan, selanjutnya dikaji berbagai materi pemecahan masalah.

Instrumen SPM ini selanjutnya dikonsultasikan dan divalidasi oleh rekan sejawat. Validasi diarahkan pada kesesuaian masalah dengan tujuan penelitian, keterbacaan, dan kesesuaian bahasa yang digunakan. Setelah dinyatakan valid oleh rekan sejawat di lanjutkan dengan uji keterbacaan kepada 5 orang mahasiswa.

Analisis dilakukan secara mendalam pada mahasiswa tentang pemecahan masalah matematika setelah subjek penelitian (mahasiswa quitter) menyelesaikan SPM dan wawancara. Analisis data dilakuan dengan cara: reduksi data, penyajian data, dan menarik kesimpulan (Miles \& Huberman, 1992). Dalam penelitian ini, dilakukan pengkajian proses konstruksi konsep matematika mahasiswa serta diagnosisnya melalui peta kognitif.

\section{HASIL PENELITIAN DAN PEMBAHASAN}

Untuk mengungkap secara lengkap proses berpikir mahasiswa Quitter dalam menyelesaikan masalah geometri dengan pemberian scaffolding menggunakan SPM. Instrumen SPM dalam penelitian ini yang sudah dinyatakan valid dan diberikan kepada mahasiswa sebagai berikut:

"Kubus ABCD.EFGH dengan panjang rusuk 6 satuan, titik $\mathrm{P}=2 / 6 \overline{C G}, \mathrm{Q}=1 / 6 \overline{\mathrm{DH}}$, $\mathrm{R}=4 / 6 \overline{A E}$. Dengan bidang frontal CDHG, sudut surut $60^{\circ}$ serta dengan perbandingan proyeksi adalah $2: 1$. Gambarlah irisan prisma ABCD.EFGH yang melalui titik $\mathrm{P}, \mathrm{Q}$ dan $\mathrm{R}$ dengan menggunakan cara sumbu afinitas".

SPM yang diberikan terkait dengan bangun ruang khususnya irisan prisma. Irisan prisma merupakan materi yang sudah diterima mahasiswa pada semester sebelumnya. Untuk menyelesaikan SPM, ada lima cara/lima proses yang berbeda yang dapat ditempuh/digunakan, kelima cara itu dapat membentuk strukrur masalah yang berbeda.

Dari hasil jawaban yang diberikan oleh subjek penelitian yaitu mahasiswa Quitter (Q1 dan Q2) terhadap SPM dan wawancara yang sudah dilaksanakan oleh peneliti, dapat dideskripsikan sebagai berikut:

1. Subjek Q1

Dari hasil menyelesaikan SPM sebelum diberikan scaffolding, Struktur masalah yang sudah dicapai Q1 dapat digambarkan seperti berikut ini: 


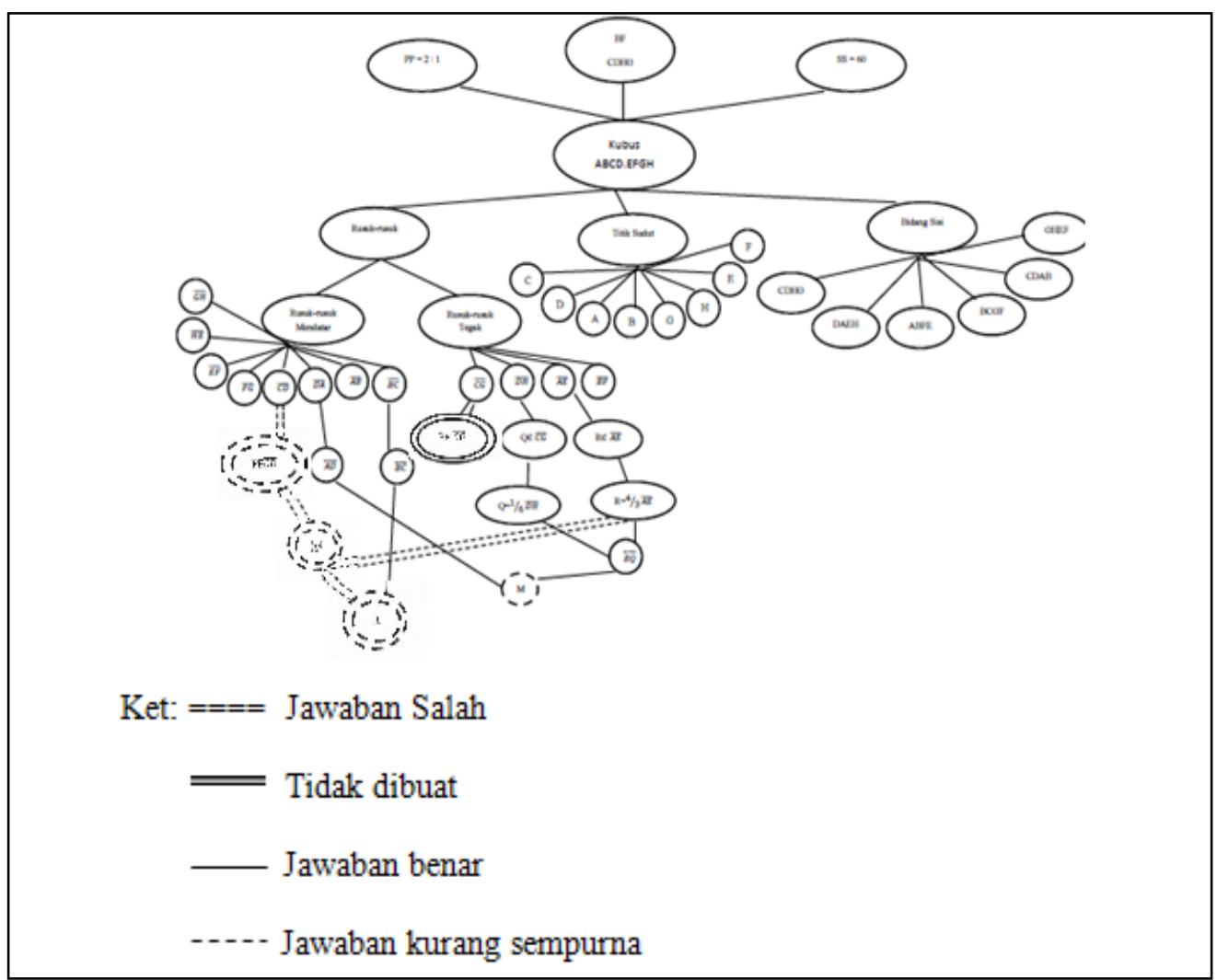

Dari hasil analisis data, Q1 untuk sampai memperoleh scaffolding sebanyak 4 kali. Proses kepada struktur masalah yang diberikan atau untuk sampai kepada proses berpikir yang sesuai dengan SPM yang diberikan, Q1 scaffolding terhadap Q1 dapat diilustrasikan pada gambar berikut. 


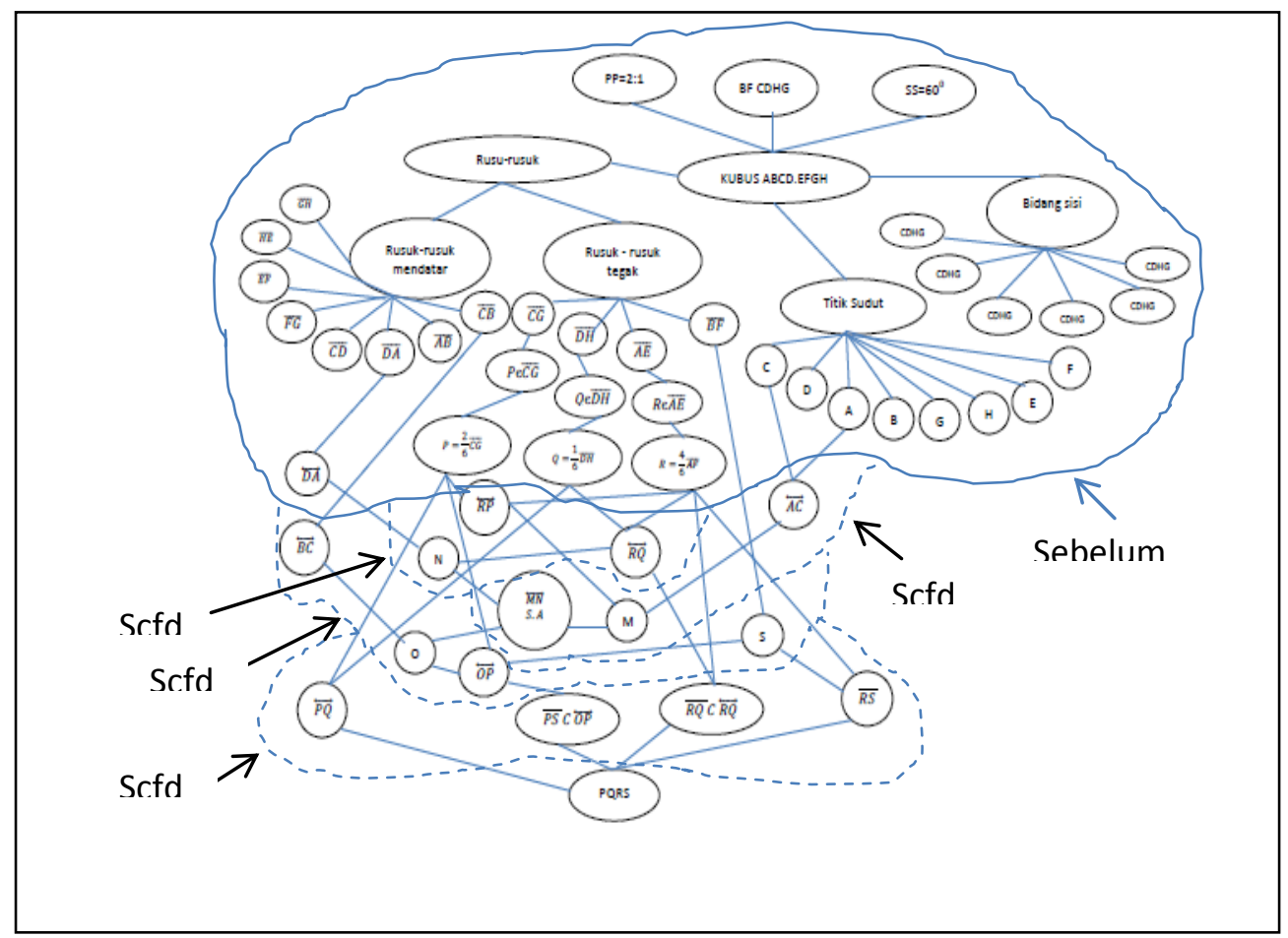

Sebelum Scfdg (strutur masalah hasil penyelesaian subjek sebelum diberikan scaffolding). Sedangkan $S c f d g$ 1, Scfdg 2, Scfdg 3 dan $S c f d g$ adalah banyaknya atau proses scaffolding yang diberikan kepada Q1. Dalam menjawab SPM, Q1 melakukan kesalahan dalam meletakkan titik $P$ sedangkan untuk titik Q dan $\mathrm{R}$ sudah benar. Selain salah meletakkan titik P, Q1 juga belum paham syarat dua garis berpotongan dan dua garis yang bersilangan. Scaffolding yang diberikan sifatnya memberikan arahan untuk meninjau dan menyusun jawaban kembali. Dalam menyelesaikan masalah Q1 mengalami perkembangan proses berpikirnya pada tahap devising a plan (merancang rencana) dan carry out the plan (melaksanakan rencana) berdasarkan penyelesaian masalah polya. Dengan 4 kali Scaffolding struktur berpikir Q1 berkembang sesuai struktur masalah yang diberikan.

\section{Subjek Q2}

Dari hasil menyelesaikan SPM sebelum diberikan scaffolding, Struktur masalah yang sudah dicapai Q2 dapat digambarkan seperti berikut ini: 


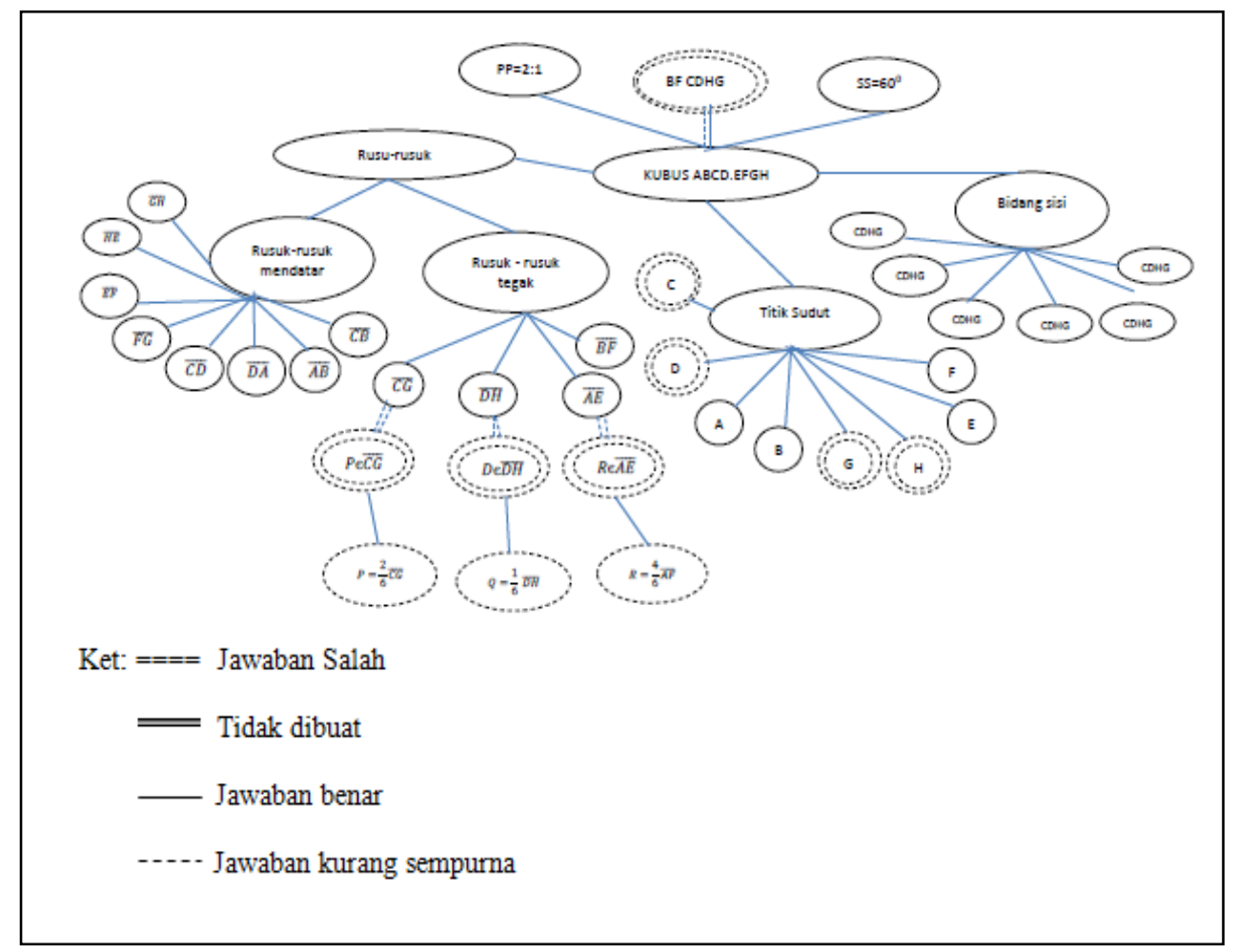

Dari hasil analisis data, Q2 untuk sampai

memperoleh scaffolding sebanyak 5 kali. Proses kepada struktur masalah yang diberikan atau untuk sampai kepada proses berpikir yang sesuai dengan SPM yang diberikan, Q2 scaffolding terhadap Q2 dapat diilustrasikan pada gambar berikut. 


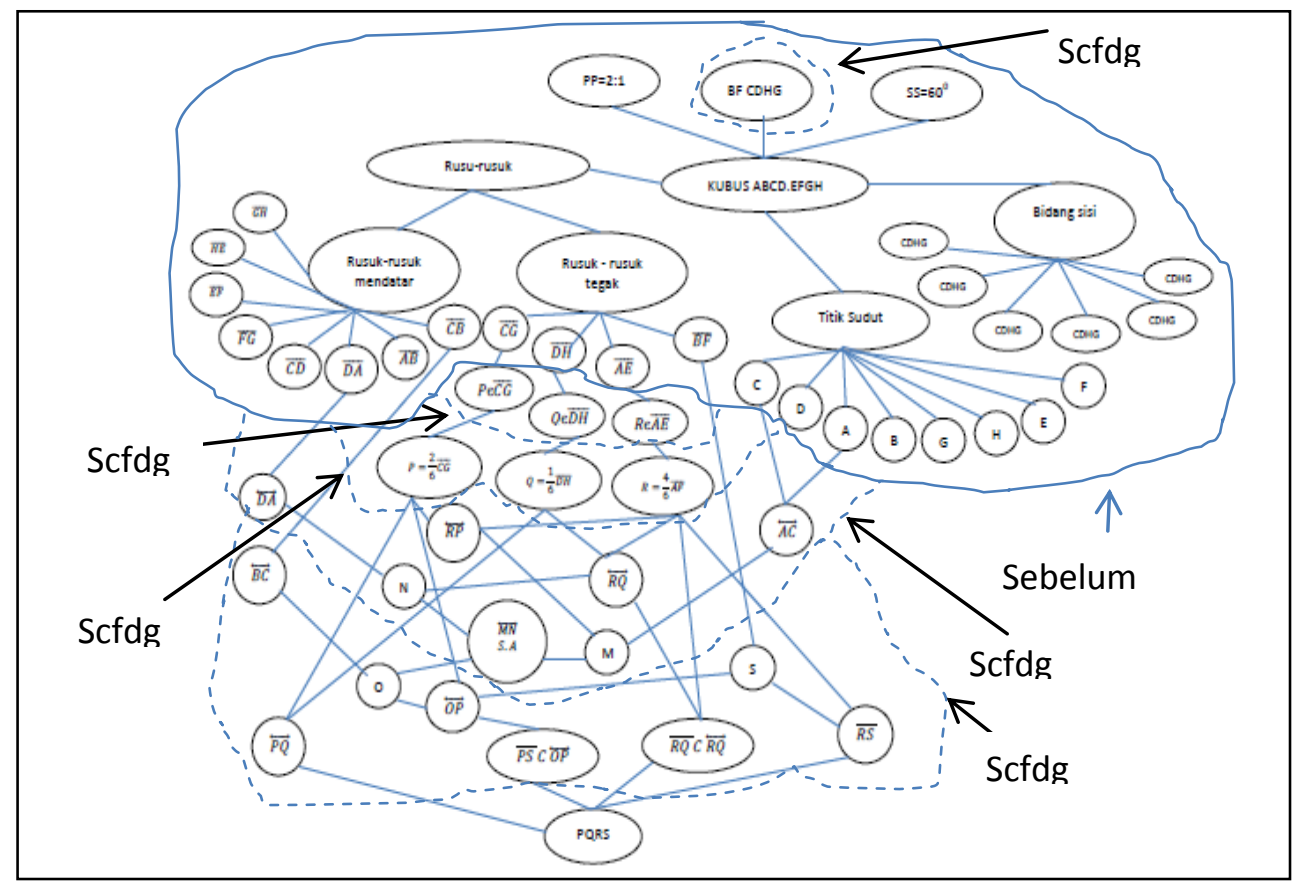

Sebelum Scfdg (strutur masalah hasil penyelesaian subjek sebelum diberikan scaffolding). Sedangkan Scfdg 1, Scfdg 2, Scfdg 3, Scfdg 4 dan Scfdg 5 adalah banyaknya atau proses scaffolding yang diberikan kepada Q2. Dalam menjawab SPM, Q2 tidak dapat menentukan bidang frontal (BF) CDHG yang sudah ditentukan dalam SPM, hal ini dikarena Q2 tidak mengerti makna bidang frontal. Dari ketidak tauan apa yang sudah diketahui terutama terkait bidang frontal mengakibatkan Q2 salah menentukan letak dari titik-titik P, Q dan R. sehingga dari jawaban Q2 diperoleh kubus ABCD.EFGH dengan bidang frontal ABFE. Dan selanjutnya Q2 menyelesaikan SPM hampir sama dengan cara penyelesaian Q1, tetapi Q2 lebih parah daripada Q1.

Scaffolding yang diberikan sifatnya memberikan arahan untuk meninjau dan menyusun jawaban kembali. Dalam menyelesaikan masalah Q2 mengalami perkembangan proses berpikirnya pada tahap understanding the problem (memahami masalah), devising a plan (merancang rencana) dan carry out the plan (melaksanakan rencana) berdasarkan penyelesaian masalah polya.
Dengan 5 kali Scaffolding, struktur berpikir Q2 berkembang sesuai struktur masalah yang diberikan.

\section{KESIMPULAN DAN SARAN}

Berdasarkan hasil penelitian dan pembahasan yang telah diuraikan di atas, bahwa proses berpikir mahasiswa Quitter dalam pemecahan masalah geometri dengan pemberian scaffolding itu unik dan menarik. Masing-masing mahasiswa memiliki cara yang berbeda dalam menyelesaikan masalah.

Adapun dalam memahami masalah kesulitan dialami oleh mahasiswa Quitter. Scaffolding yang diberikan bervariasi sesuai kebutuhan masing-masing mahasiswa untuk mengembangkan proses berpikirnya. Dengan pemberian scaffolding pada umumnya proses berpikir subjek penelitian berkembang sesuai struktur masalah.

Menyarankan pada dosen untuk memahami proses berpikir mahasiswa dalam pemecahan masalah irisan prisma, sehingga dapat memberikan bantuan yang tepat bagi mahasiswa agar dapat meningkatkan 
kemampuannya dalam menyelesaikan masalah irisan prisma. Kajian tentang proses berpikir mahasiswa Quitter dalam penelitian ini merupakan studi kasus sehingga hanya terbatas pada masalah irisan prisma di semester 3, untuk itu perlu kajian lagi dengan subjek yang berbeda.

\section{DAFTAR KEPUSTAKAAN}

Anghileri J. 2006. Scaffolding Practic-es That Enhance Mathematics Learning. Journal of Mathematics Teacher Education, 9.33 -5 .

Herlambang. 2013. Analisis Kemampuan Pemecahan Masalah Matematika Siswa Kelas VII-A SMP Negeri 1 Kepahiang Tentang Bangun Datar Ditinjau Dari Teori Van Hielle. Tesis. Bengkulu: PPS Universitas Bengkulu.

Imamuddin M. 2012. Pembelajaran Matematika dengan Pendekatan Problem Posing (Pengajuan Masalah/Soal) untuk Meningkatkan Kemampuan Berpikir Kreatif. Jurnal ANALISIS, Vol. 9, No. 2, Juli-Desember, STAIN Bukittinggi.

Marpaung Y.1999 . Mengejar Ketertinggalan Kita dalam Pendidikan Matematika Mengutamakan Proses Berpikir dalam Pembelajaran Matematika. Makalah disampaikan dalam Upacara Pembukaan Program S3 Pendidikan Matematika Universitas Negeri Surabaya, Tanggal 10 September.
Polya G. 1973. How to Solve It. New Jersey: Princeton University Press.

Rosdiana \& Misu L. 2013. Pengembangan teori pembelajaran perilaku dalam Kaitannya dengan kemampuan pemecahan masalah Matematik siswa di SMA. Prosiding Seminar Nasional Matematika dan Pendidikan Matematika FMIPA UNY. Yogyakarta: Universitas Negeri Yogyakarta.

Ruggiro, Vincent R. 1998. The Art of Thinking. A Guide to Critical and Creative Thought. New York: Longman, An Imprint of Addison Wesley Longman, Inc.

Saad NS \& Ghani AS. 2008. Teaching Mathematics in Secondary School: Theories and Practices. Perak: Universiti Pendidikan Sultan Idris.

Stoltz PG. 2000. Adversity Quotient: Mengubah Hambatan Menjadi Peluang. Jakarta: Gramedia Widiasarana Indonesia.

Suryabrata Sumadi. 1990 . Psikologi Pendidikan. Jakarta: CV Rajawali.

Syaiful. 2012. Peningkatan Kemampuan Pemecahan Masalah Matematis Melalui Pendekatan Pendidikan Matematika Realistik. Edumatica, 2, (1), 36-44

Yulaelawati E. 2004. Kurikulum dan Pembelajaran: Filosofi Teori dan Aplikasi, Bandung: Pakar Raya.

Yuwono A. 2010. Profil Siswa SMA Dalam Memecahkan Masalah Matematika Ditinjau dari Tipe Kepribadian. Tesis. Surakarta: PPS Universitas Sebelas Maret. 